\title{
Global and Regional Sharia Stock Exchange: A Case Study in America, Saudi Arabia, Bahrain and Kuwait
}

\author{
Lisa Kustina ${ }^{1}$, Megawati ${ }^{2}$ \\ Pelita Bangsa University ${ }^{1}$, Pelita Bangsa University ${ }^{2}$ \\ Email: lisakustina@pelitabangsa.ac.id
}

\begin{abstract}
This study aims to examine the effect of global sharia stock exchanges (America, Saudi Arabia, Bahrain, and Kuwait) on regional sharia stock exchanges (Indonesia). This study is a quantitative research in which the research sample taken from Indonesian stock market (Jakarta Islamic Index), American stock exchange (Dow Jones Islamic Industrial Average), Middle-Eastern stock (Tadawul All Share, Bahrain All Share, and Premier Market-Market Cap Weighted PR). The data analysis method used is linear regression analysis and the data is processed using Eviews 10 software. The data period used in this study is one year (2018) using the weekly data period. Overall Linear Regression test results using Eviews 10 software shows that the Bahrain All Share (BAX) has a positive and significant effect on the Jakarta Islamic Index (JII), while the Dow Jones Industrial Average (DJIA), Tadawul All Share (TASI), Premier Market-Market Cap Weighted PR (BKP) has no significant effect on the Jakarta Islamic Index (JII).

Keywords: Dow Jones Industrial Average (DJIA), Tadawul All Share (TASI), Premier Market- Market Cap Weighted PR (BKP), Jakarta Islamic Index (JII).
\end{abstract}

\section{Introduction}

Investment in Indonesia is currently experiencing a fairly good development. This is indicated by the improved performance of the Composite Stock Price Index (IHSG), LQ45, Jakarta Islamic Index (JII), and the Indonesian Syariah Stock Index (ISSI), which represents the actual conditions of the national Islamic capital market (Beik \& Fatmawati, 2014). The capital market as a means to invest and funding for the government or other agencies trades long-term financial instruments (Martalena and Malinda, 2011: 2). Investors can provide funds to companies that issue shares called issuers. The Sharia capital market in Indonesia is part of the international Sharia capital market. The Jakarta Islamic Index (JII) is a benchmark of performance in selecting sharia-based stock portfolios and increasing investor confidence in developing investments in sharia equity or to provide opportunities for investors who wish to invest according to sharia principles (Beik, 2014). The increase or decrease in the value of the shares was apparently influenced by internal and external factors. The external factor can come from other countries' stock indexes. The stock price index is used to describe the situation of the stock market and is a parameter used as a reference for investors, analysts and the public. 


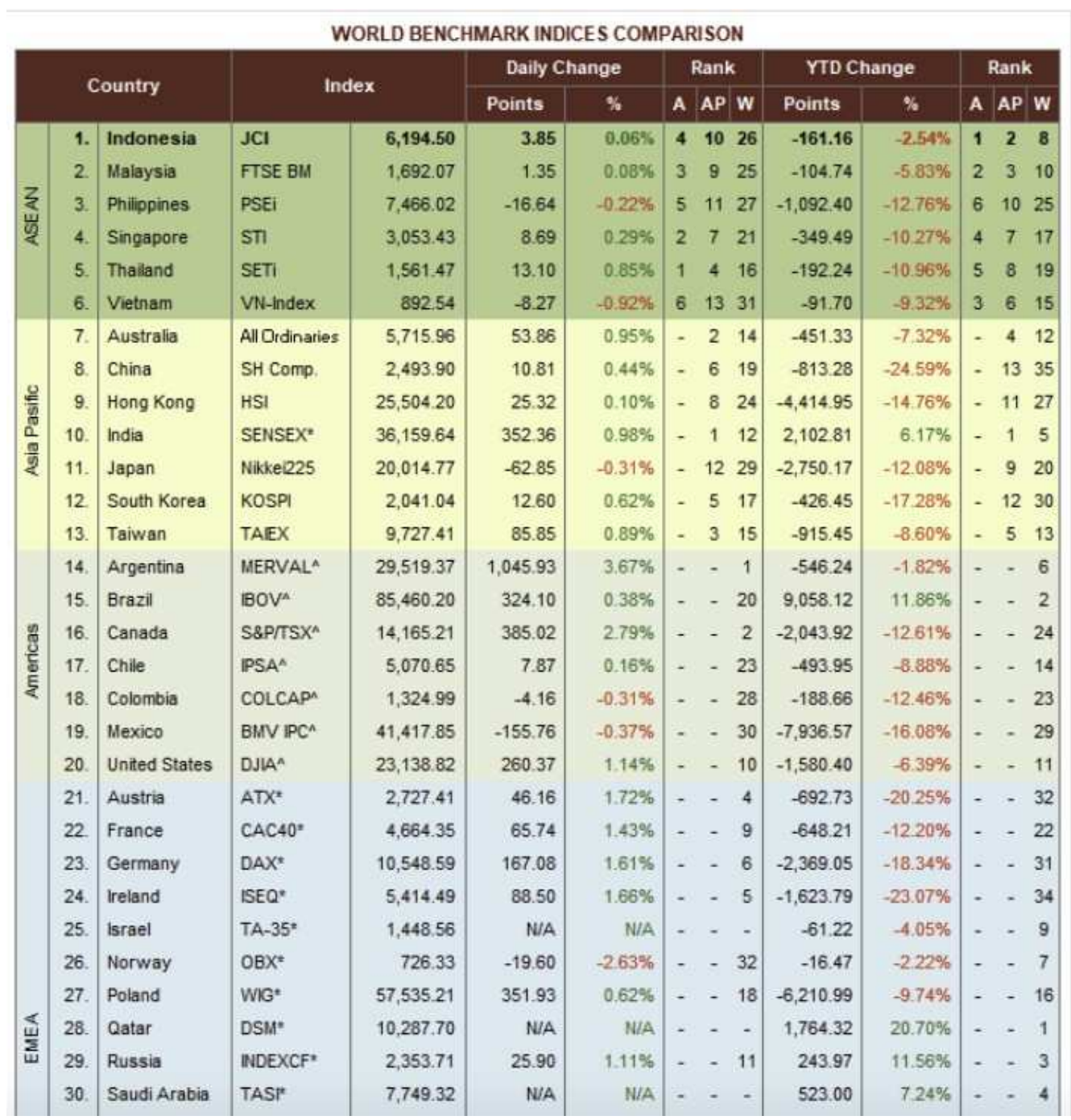

Fig.1. World Benchmart Indices Comparison Source: Idx

Based on Figure 1 it can be concluded that the American index affects the index in Indonesia, while according to 2018 data the shares in the Middle East have not decreased compared to the others. Qatar and Saudi Arabia shares tend to rise from other Asian indices that experience a decline except India. Middle East shares do not experience a decline because the number of investors is limited by $5 \%$, while in Indonesia the number of investors is $75 \%$.

Manihuruk and Darmawan (2017) found that the BI Rate, Fed Râte, the Dow Jones Index, and the Shāhghai Index have simultaneously had a significant effect on the IHSG. Immediately, only the Dow Jones Index has a significant positive impact on the IHSG. Whereas Aditya (2017) found that GDP, Inflation, JUB, interest rates, exchange rates, world oil prices and DJIA together influence the changes in JII stock returns. 


\section{Literature Review}

The Jakarta Islamic Index (JII) is a sharia stock index which was first launched on the Indonesian capital market on July 3, 2000. The JII constituency consists of only the 30 most liquid Islamic stocks listed on the IDX. Just like ISSI, a review of Shariah shares that are JII constituents is conducted twice a year, in May and November, following the schedule of DES review (List of Sharia securities) by Financial Services Authorities (OJK). The development of Islamic instruments in the capital market has occurred since 1997. The Dow Jones Industrial Average (DJIA) is an index that tracks 30 large public companies traded on the New York Stock Exchange (NYSE) and NASDAQ. DJIA was named by Charles Dow, who created it in 1896, and his business partner, Edward Jones. DJIA is one of the oldest and most considered indices in the world, including companies such as the Walt Disney Company, Exxon Mobil Corporation and Microsoft Corporation.

Tadawul All Share (TASI) is a major stock market index that tracks the performance of all companies listed on the Saudi Stock Exchange. This index had a base value of 1000 in 1985 and was reorganized on June 30, 2008. On March 19, 2007, the Council of Ministers approved the creation of the Saudi Stock Exchange. The Capital Market Law Article-20 stipulates Tadawul as a joint stock company. Tadawul is the only entity authorized in the Kingdom of Saudi Arabia to act as an Exchange.

Bahrain All Share (BAX) is a major stock market index that tracks the performance of company shareholders listed on the Bahrain Exchange. This is a capitalized weighted index. BAX is a stock market index that tracks the performance of large companies based in Bahrain. Premier Market- Market Weighted Cap is one of the Kuwaiti stock exchanges. The Kuwait Exchange is a member of the Euro-Asia Stock Exchange Federation. The stock market in Kuwait is regulated by four bodies namely: KSE, the Ministry of Trade and Industry, the Ministry of Finance and the Central Bank of Kuwait. KSE is also one of the first and largest stock exchanges in the Persian Gulf region.

H1: Dow Jones Industrial Average has a significant positive effect on the Jakarta Islamic Index. H2: Tadawul All Share has a significant positive effect on the Jakarta Islamic Index. H3: Bahrain All Share has a significant positive effect on the Jakarta Islamic Index. H4: Premier Market- Market Weighted PR has a significant positive effect on the Jakarta Islamic Index

\section{Research Methods}

This study is a quantitative research. The sample was obtained from the Indonesian stock market particularly in the Jakarta Islamic Index (JII), the American stock exchange (Dow Jones Islamic Industrial Average), the Middle-East exchange (Tadawul All Share), Bahrain All Share, and Premier Market-Market Cap Weighted PR). The data was analysed with linear regression analysis and the data is processed using Eviews 10 software. The data period used in this study is one year (2018) using the weekly data period. The independent variables in this study are the Dow Jones Industrial Average (X1), Tadawul All Share (X2), Bahrain All Share (X3), Premier Market-Market Cap Weighted PR (X4), while the dependent variable in this study is the Jakarta Islamic Index (Y). 


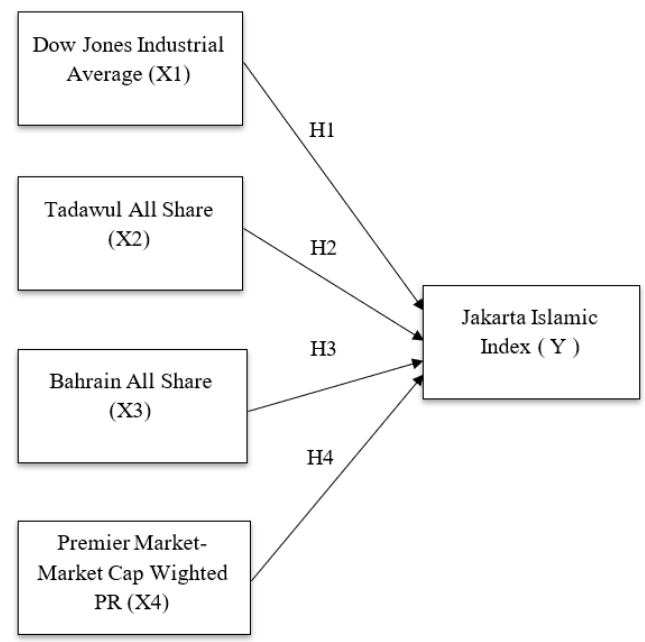

Fig.2. Research Desain

\section{Result and Discussion}

The multiple linear analysis test is used to examine the effect of several independent variables on one dependent variable with the metric data type (ratio). Partially, the Dow Jones Industrial Average (DJIA) has no significant effect on JII where the probability result is 0.3974 , the probability value that exceeds the test standard, 0.05 . Therefore, it can be concluded that the Dow Jones Industrial Average (DJIA) does not have a significant effect on JII with a coefficient value of DJIA that is 0.003044 . This is caused by issuers that are indexed by DJIA are conventional. As a result, they impact on IHSG (Pratama, 2012). These results are consistent with research conducted by Ghiffari, Kindangen \& Tumewu (2017) and also Janitra (2014) and Pratama \& Azzis (2018) which state that DJIA has no significant effect on JII.

\begin{tabular}{lrrrr}
\hline \hline \multicolumn{1}{c}{ Variable } & Coefficient & Std. Error & t-Statistic & Prob. \\
\hline \hline C & -1.525137 & 2.270890 & -0.671603 & 0.5052 \\
$D(\mathrm{DJIA})$ & 0.003044 & 0.003563 & 0.854321 & 0.3974 \\
$\mathrm{D}(\mathrm{TASI})$ & 0.021465 & 0.014628 & 1.467409 & 0.1491 \\
$\mathrm{D}(\mathrm{BAX})$ & 0.419098 & 0.182579 & 2.295436 & 0.0263 \\
$\mathrm{D}(\mathrm{BKP})$ & -0.014560 & 0.009518 & -1.529629 & 0.1330 \\
\hline \hline & 0.196087 & Mean dependentyar & & -1.038039 \\
R-squared & 0.126181 & S.D. dependentyar & & 17.18435 \\
Adjusted R-squared & 16.06364 & Akaike infocriterion & & 8.483887 \\
S.E. of regression & 11869.86 & Schwarz criterion & & 8.673282 \\
Sum squared resid & -211.3391 & Hannan-Quinn criter. & & 8.556261 \\
Log likelihood & 2.805025 & Durbin-Watson stat & & 2.415416 \\
F-statistic & 0.036388 & & & \\
Prob(F-statistic) & & & & \\
\hline \hline
\end{tabular}

Fig.3. Regresion analysis output Source: eviews, 2020 
Partially, Tadawul All Share (TASI) has no significant effect on JII where the probability result is 0.1491 , the probability value that exceeds the test standard is 0.05 . Thus, it can be concluded that Tadawul All Share (TASI) has no significant effect on JII and the Coefficient value of TASI is 0.021465 . This is probably the reason that foreign investors in the Saudi Arabia Stock Exchange are limited by $5 \%$ so that the volatility is small. Whereas in Indonesia the maximum is $75 \%$, so the volatility is higher than the Saudi Arabian stock exchange. This proves Tadawul All Share has no effect on JII. This is consistent with research conducted by Miniaouni, Sayani, Chaibi (2015).

Partially, Bahrain All Share (BAX) has a positive and significant effect on JII where the probability result is 0.0263 , the probability value is below the test level value of 0.05 . It can be concluded that the Bahrain All Share (BAX) has a significant effect on JII with a Coefficient value of BAX 0.419098. According to (Miniaoui, Sayani and Chaibi, 2015) this happened due to the financial crisis which has an impact on volatility in three GCC markets (Kuwait, Bahrain, and UAE). These results are consistent with the research of Miniaoui, Sayani and Chaibi (2015) which states that BAX has a positive and significant effect on JII.

Partially, BKP has no significant effect on JII where the probability result is 0.1330 where the probability value exceeds the test standard, 0.05 . Hence, it can be concluded that the BKP has no significant effect on the JII and the Coefficient value of the BKP is -0.014560 . This is due to the weak form of patterns and price trends (Almujamed, Fifield \& Power, 2018). These results are in accordance with Almujamed, Fifield \& Power (2018) research which states that BKP has no significant effect on JII.

\section{Conclusion}

Overall Linear Regression test results using Eviews 10 software shows that the Bahrain All Share (BAX) has a positive and significant effect on the Jakarta Islamic Index (JII), while the Dow Jones Industrial Average (DJIA), Tadawul All Share (TASI), Premier Market-Market Cap Weighted PR (BKP) has no significant effect on the Jakarta Islamic Index (JII).

\section{References}

[1] Almujamed, Fifield \& Power. 2018. An Investigation of the Weak Form of the Efficient Markets Hypothesis for the Kuwait Stock Exchange. Journal Of Emerging Market Finance 17 (I) Hal. 128,2018 .

[2] Aditya. 2017. Pengaruh Variabel Makro Ekonomi Terhadap Return Saham Perusahaan Yang Tercatat Di Jakarta Islamic Index (JII) Periode 2011 - 2015. OECONOMICUS Journal Of Ekonomics, Volume 1, No. 2, Desember 2017

[3] Beik \& Fatmawati. Pengaruh Indeks Harga Saham Syariah Internasional Dan Variabel Makro Ekonomi Terhadap Jakarta Islamic Index. Al-Iqtishad: Vol. VI, No. 2, Juli 2014.

[4] Janitra, E. Do World Gold Price, Dow Jones Islamic Market And Inflation Affect The Performance Of Jakarta Islamic Index? Jurnal Ekonomi dan Studi Pembangunan. 15(2). 97-108 2014

[5] Ghiffari, Kindangen, Tumewu, 2017. Hubungan Kausalitas Dow Jones Industrial Average (Djia) Dan Nikkei 225 Terhadap Jakarta Composite Index (Jci) Periode 2011- 2016. Jurnal EMBA Vol. 5, No.2, Juni 2017, Hal. 445-454

[6] Manihuruk \& Darmawan. 2017. Pengaruh Bi Rate, Fed Rate, Indeks Dow Jones, Dan Indeks Shanghai Terhadap Indeks Harga Saham Gabungan (Studi pada Bursa Efek Indonesia Periode 
2009-2016). Jurnal Administrasi Bisnis (JAB), Vol. 52, No. 1 November 2017.

[7] Miniaouni, H; Sayani, H; Chaibi, A. The Impact Of Financial Crisis On Islamic And Conventional Indices Of The GCC Countries. The Journal Of Applied Business Research. 31(2)(2015) 